\title{
PeRempuan punkz Budaya perlawanan TERHADAP GENDER NORMATIF (Kasus di Desa Cijambe Ujung Berung)
}

\section{PUNKS WOMEN: COUNTER CULTURE AGAINST NORMATIVE GENDER (A STUDY CASE IN CIJAMBE VILLAGE, UJUNG BERUNG)}

\author{
Ani Rostiyati dan Aquarini Priyatna \\ Peneliti Utama Balai Pelestarian dan Nilai Budaya Bandung \\ Jl. Cinambo No. 136 Ujungberung - Bandung \\ e-mail: anirostiyati@yahoo.com
}

\begin{abstract}
Abstrak
Punk merupakan sekelompok orang yang memiliki budaya tersendiri, berbeda dengan budaya yang lebih banyak dipraktikkan orang. Punk dicirikan sebagai bentuk budaya tanding yakni perlawanan terhadap budaya dominan. Tulisan ini bertujuan untuk mengemukakan cara perempuan punk mengidentifikasi dirinya melalui makna penampilan dan fashion yang dikenakan, sehingga terungkap ide, gagasan, dan cara pandang mereka dalam meresistensi diri dari kontruksi gender normatif. Hasil penelitian terungkap bahwa dalam estetika punk, mereka berupaya untuk menghilangkan diri dari budaya dominasi dan gender normatif yang diresepkan. Mereka keluar dari pusat patriarki dan menentang ide-ide feminitas. Penelitian ini berupa studi kasus terhadap 5 (lima) perempuan punk di Ujung berung Bandung dan dikaji secara mendalam dengan menggunakan pendekatan kualitatif utuk memperoleh data akurat, menyeluruh, dan detail mengenai makna penampilan perempuan punk. Jenis penelitian bersifat analisis deskriptif yakni menganalisis dan menyajikan fakta sehingga lebih mudah untuk dipahami dan disimpulkan. Adapun pengambilan data melalui observasi, wawancara mendalam, foto, dan studi pustaka.

Kata kunci: perempuan punk, budaya perlawanan, gender normatif.
\end{abstract}

\begin{abstract}
Punk is a group of people who have their own culture, unlike the more widely practiced cultures. Punk is characterized as a form of sparring culture that is the opposition to a dominant culture. Counter culture movements are expressed in various forms of identity, such as, work, and lifestyle to show their ideology and ideals. This paper aims to reveal women punk, based on their appearance or fashion that has a symbolic meaning as a form of resistance to normative gender that tends to be established. A dirty, dull punk, a "sneaky" behavior shows resistance against something considered ideal. This paper also wants to find out how punk women identify themselves through the meaning of appearance and fashion, so that their ideas, and perceptions are expressed in self-respecting of normative gender constructions. The results reveal that in a punk aesthetics, they seek to remove themselves from the normative dominance culture and gender that are prescribed. They emerge from the patriarchal center and oppose the ideas of femininity. Punk women have different gender experiences and relationships with women in general, this can be seen from gender acts (gender aesthetics). Punk women exhibit gender acts subjectively that are not subject to social rules as their identity. This research is a case study of 5 (five) punk women in the Edge of Bandung and studied in depth using qualitative approach. With a qualitative approach, it will obtain accurate, comprehensive and detailed data about the actions and the meaning behind the appearance of punk women. The type of research is descriptive
\end{abstract}


analysis which analyzes and presents facts systematically. Therefore, it is easier to understand and concluded. The data collection through observation, in-depth interview, photo and literature study.

Keywords: Punk Women, counter culture, and normative gender.

\section{A. PENDAHULUAN}

Jeans belel, asesoris rantai, tindik, tato, rambut cat warna warni, dan sepatu lars adalah penampilan punk yang unik. Apalagi dikenakan oleh perempuan punk yang dikatakan sebagai suatu keberanian dalam menentang busana yang biasa dikenakan oleh kaum perempuan kebanyakan, yang umumnya ingin tampil cantik, anggun, sopan, bersih dan menarik. Inilah salah satu hal yang menarik perhatian untuk dikaji lebih dalam mengapa mereka mengenakan fashion seperti itu, identitas dan gaya hidup apa yang akan mereka tampilkan sebagai bentuk perlawanan terhadap gender normatif. Gender normatif menurut Sharifah (2016: 28) adalah memperkuat atau memaksa standar ideal dari kemaskulinan atau kefemininan. Sebagai contoh bahwa perempuan harus pintar memasak, berdandan, mengurus anak dan suami atau laki-laki harus bekerja di luar, ini gender normatif yang akhirnya berubah menjadi tidak berkuasa pada dirinya sendiri dan di masyarakat. Tulisan ini ingin membahas tentang perempuan punk yang ditilik dari segi penampilannya sebagai bagian dari budaya masyarakat. Penampilan yang terdiri dari berbagai atribut ini memiliki makna simbolis sebagai bentuk perlawanan terhadap budaya dominan yang cenderung ideal. Pakaian punk yang kotor, belel, kelakuan yang "nyeleneh" menunjukkan perlawanan terhadap sesuatu yang ideal. Menurut Ary Prasetyo Frans peneliti mandiri asal Bandung dalam suatu diskusi tentang "Punk, Penentangan dan Politik Transnasionalisme" (2017) mengatakan bahwa:

"Inti dari punk adalah tanpa kompromi dan perlawanan terhadap otoritas. Ini dapat dilihat dari "Fashion Punks", tantangan terhadap otoritas, dan sikap penolakan terhadap legitimasi dari otoritas. Karenanya, punk menemukan ekspresi politis dalam anarkisme atau bentuk lain dari anti otoritas. Fashion punks ikut meramaikan dalam menyampaikan pikiran, kritik sosial, protes terhadap norma sosial yang diekspresikan melalui penampilannya. Punk menggunakan musik dan fashion sebagai simbolisasi dan bentuk spektakuler dari perlawanan dan resistensi"

Sejalan dengan apa yang diuraikan di atas maka tujuan kajian ini adalah mengemukakan cara perempuan punk mengidentifikasi dirinya melalui makna penampilan dan fashion yang dikenakan, mulai dari baju, rambut, tata rias, dan asesoris yang dikenakan, sehingga terungkap ide, gagasan, dan cara pandang mereka dalam meresistensi diri dari kontruksi gender normatif. Mengungkap bagaimana perempuan punk membangun identitas dan gaya hidupnya serta kedudukannya terhadap dominasi laki-laki dan budaya patriarkat.

Komunitas punk tidak hanya terdiri dari anak laki-laki. Fenomena yang saya lihat, anak perempuan juga termasuk di dalamnya. Namun sedikit sekali perempuan yang masuk dalam komunitas punk.

Punk menurut Irwan Abdullah (2006: 1999) merupakan budaya tanding (counter culture) yakni bentuk perlawanan dari budaya dominan. Budaya dominan adalah jenis budaya yang menguasai masyarakat (kelas penguasa), sedangkan budaya tanding adalah sub budaya yang berada dalam posisi pinggiran (periferal). Budaya pinggiran bisa menjadi bentuk budaya tanding ketika agen budaya tanding 
ini menolak untuk mengikuti gaya kelas yang mempraktikkan budaya dominan. Budaya tanding memadukan dua bentuk protes yaitu penentangan terhadap nilai dominan, dan struktur kekuasaan. Budaya dominan biasanya melahirkan budaya bisu, budaya patuh, tunduk dan takut. Ini pola komunikasi yang diciptakan penguasa (Agger, 2014: 105). Budaya tanding biasanya mencoba bersuara untuk menyampaikan gagasan untuk menjelaskan identitas, pikiran, gaya hidup dan citacitanya. Hal ini juga dikemukakan oleh Dominic (2004: 29) bahwa budaya tanding mengacu pada gaya hidup yang menyimpang dari praktik sosial yang telah mapan. Budaya tanding yang terkenal dengan nama punk ini menunjukkan gaya hidup dengan penampilan yang unik.

Sebagai budaya tanding terhadap budaya dominan kapitalis, punk sudah menyebar kemana-mana di seluruh Indonesia. Punk sebagai budaya tanding sifatnya kritis terhadap budaya dominan. Ekspresi budaya perlawanan individual melahirkan budaya tanding seperti budaya punk yang menolak konsumerisme dan membangun kemandirian serta kebebasan.

Menurut Irwan Abdullah (2015: 199) punk juga memiliki ciri-ciri budaya jalanan, karena mereka lepas menyimpang dari budaya induknya yang mapan ingin mandiri dan kebebasan. Budaya jalanan bukan sekedar budaya yang timbul di jalan, tetapi suatu kecenderungan sistem berpikir, nilai, dan praktik sosial yang lepas menyimpang dari budaya induknya yang dianggap mapan.

Penelitian ini dilakukan di Ujung Berung Bandung, tepatnya di Kelurahan Cijambe dengan alasan di lokasi tersebut banyak ditemui komunitas perempuan punk, bahkan menurut sejarahnya di lokasi tersebut awal tumbuhnya punk di Bandung.

Seorang tokoh punk terkenal di Bandung bernama Kimung (2012: 23) menceritakan bahwa Ujung Berung dikenal dengan pusatnya anak punk, mereka tinggal secara mandiri hidup di kos atau rumah kontrakan. Mereka tinggal mengelompok atau bersama dan membayar rumah kontrakan atau indekos secara patungan, baik yang masih lajang maupun sudah menikah. Setiap malam minggu atau libur dan ada even musik, mereka keluar dan berkumpul untuk kebersamaan dan mencari kebebasan. Saat seperti itu mereka tampil dengan atribut punknya.

Secara teoritis, hasil penelitian ini memberikan sumbangan pemikiran bagi pemerintah, bagaimana upaya pembinaan, pengembangan dan penerimaan terhadap kelompok minoritas ini. Untuk melihat identitas dan gaya hidup mereka, peneliti menggunakan teori performativitas Judith Butler, identitas dari Stuart Hall, dan gaya hidup dari Suwardi.

Terkait kajian tentang perempuan punk tidak bisa dipisahkan dengan identitas gendernya. Identitas menurut Hall sebagaimana yang dikutip oleh Butler (1990) berkaitan dengan konsepsi yang dimiliki individu tentang dirinya sendiri dan citra diri individu itu di mata orang lain. Identitas merujuk pada pertanyaan tentang siapa perempuan punk dan bagaimana orang lain melihatnya. Identitas itu bukan sesuatu yang given, tetapi sebuah produksi yang tidak pernah final, selalu dalam proses dan dikontruksi direkontruksi dalam sistem penandaan atau representasi. Yudith Butler (1990) dalam bukunya gender trouble mengatakan bahwa identitas itu dibentuk secara performatif melalui wacana, tidak muncul by nature di masyarakat atau ada sejak lahir, melainkan dibentuk secara performativitas. Jadi identitas gender itu adalah efek yang diproduksi oleh individu karena menampilkan secara berulang tindakan atau praktik yang secara sosial diterima sebagai penanda identitas laki-laki atau perempuan.

Tindakan atau praktik itu oleh Butler diistilahkan sebagai gender acts. Performativitas gender menyiratkan bahwa individu membentuk identitas gendernya, seperti layaknya memilih baju. Untuk 
menjadi seorang perempuan misalnya, individu akan memilih baju yang secara sosial dianggap menampilkan femininitas. Jadi pilihan baju, cara berjalan, bermake up, bertingkah laku feminim itu bukan produk identitas feminim. Identitas feminim diperoleh karena individu menampilkan sikap dan perilaku berulang. Buttler mengatakan bahwa gender acts tersebut tidak diinternalisasi oleh tubuh, tetapi dilekatkan atau ditorehkan pada tubuh.

Oleh karena itu menurut Buttler gender tidak lebih dari a corporeal style (segala sesuatu yang melekat pada fisik tubuh) yang bertahan secara sosial, karena jika individu tidak menampilkan gendernya secara "benar" maka mereka akan "dihukum" oleh masyarakat. Individu dalam hal ini, memang bisa memilih untuk menampilkan gender acts-nya, namun pilihan itu sudah disediakan oleh norma yang disepakati secara sosial atau masyarakat. Norma sosial ini membatasi individu dalam mengkontruksi identitasnya. Jadi norma sosial inilah yang mengikat individu tersebut untuk menampilkan gender acts nya. Buttler mengatakan hal ini sebagai gender normatif yakni norma sosial yang memperkuat atau memaksa standar ideal dari kemaskulinan atau kefeminiman.

Namun, menurut Buttler juga menyebutkan bahwa agensi individu tidak sepenuhnya tunduk atau dibatasi oleh norma-norma tersebut, karena performativitas itu melibatkan reiterated practices yaitu proses repetisi gender acts yang dilakukan oleh individu. Ketika melakukan repetisi tersebut, individu bisa juga melakukan modifikasi radikal atau menampilkan gender acts tersebut secara subversif untuk menggoyang prinsip gender yang diterima secara sosial, meskipun bisa jadi "dihukum" oleh masyarakat. Perempuan punk sebagai contoh bagaimana melakukan perlawanan terhadap gender normatif, yang diekspresikan melalui performativitas gender yang membentuk identitas dan gaya hidup yang menyimpang dari praktik sosial yang sudah mapan. Perempuan punk menempati tempat yang berbeda dalam gender acts nya, bagaimana mereka melepaskan diri dari dominasi budaya dan gender normatif yang diresepkan. Perempuan punk adalah perempuan yang pergi dari pusat patriarkal untuk mencari kebebasan dan kemandirian.

Gaya hidup (Hasan, 2011: 221) adalah suatu cara individu mengekspresikan atau mengaktualisasikan kebiasaan, cita-cita, hobi, opini dan lain sebagainya, dengan lingkungannya melalui cara unik yang menyimbolkan status dan peran. Gaya hidup bisa dijadikan jendela dan kepribadian. Tiap individu berhak punya gaya hidup mana yang dijalani seperti gaya hidup mewah, sederhana, termasuk gaya hidup punk yang anti kemapanan dan kebebasan.

Menurut Vicous seperti yang dikutip oleh Sandi Suwardi Hasan (2011), mengkaji punk tidak lepas dari 4 (empat) faktor yakni musik, fashion (penampilan), tempat tongkrongan, dan ideologi atau cara pandang. Untuk membatasi masalah, dalam kajian ini hanya membatasi gaya penampilan atau fashion saja yang tercermin dari pakaian, asesoris yang dipakai, tata rias muka dan rambut, sepatu, tindik dan tato.

\section{B. METODE PENELITIAN}

Penelitian ini merupakan studi kasus terhadap 5 (lima) perempuan punk yang diteliti secara mendalam dan menggunakan pendekatan kualitatif. Adapun pendekatan kualitatif digunakan untuk menganalisis terhadap dinamika hubungan antarfenomena yang diamati dengan menggunakan logika ilmiah. Pendekatan kualitatif ini menekankan data-data yang bersifat gagasan, ide, nilai-nilai, dan pikiran yang tidak bisa diukur dengan angka (Miharja, 2012: 12). Pendekatan ini dilakukan pada usaha menjawab pertanyaan melalui cara berfikir formal dan argumentatif. Bila dilihat dari kedalaman analisisnya, maka jenis 
penelitian bersifat analisis deskriptif yakni menganalisis dan menyajikan fakta secara sistematik sehingga dapat lebih mudah untuk dipahami dan disimpulkan. Penelitian deskriptif menggambarkan secara sistematik dan akurat mengenai populasi atau bidang tertentu, dalam hal ini punk perempuan di Ujung Berung Bandung. Adapun pengambilan data melalui observasi, wawancara mendalam pada kelima informan, bagaimana mereka mengidentifikasi dirinya sebagai punk, bagaimana fashion dan asesoris berkontribusi terhadap identitasnya, dan bagaimana perempuan punk meresistensi konstruksi gender normatif.

\section{Tinjauan Pustaka}

Beberapa hasil bacaan akan dikemukakan berikut ini sebagai pembanding dan tinjauan pustaka untuk mengetahui sejauh mana tulisan tentang perempuan punk ini pernah ditulis dan dikaji. Agar tidak terjadi penulisan ulang dan benar-benar yang ditulis adalah sesuatu yang baru belum pernah dikaji dan memberi manfaat pada pemerintah dan masyarakat.

Komunitas punk banyak ditemui di Ujung Berung Bandung, bahkan menurut sejarah di lokasi tersebut awal tumbuhnya punk di Bandung. Tulisan Andre Palebangan Bana (2007) dalam bukunya berjudul "Catatan Kecil Punk Ujung Berung", melakukan penelitian tentang profil komunitas punk di Ujung Berung Bandung, meneliti tentang awal mulanya terbentuk komunitas punk, faktor yang melatarbelakangi komunitas punk, aktivitas punk, dan interaksi punk dengan punk dan di luar kelompok punk. Hasil penelitian menunjukkan bahwa komunitas punk menganut ideologi anarkisme dan menganut etika do it your self (dikerjakan sendiri).

Penelitian ini juga menunjukkan aktivitas komunitas punk baik dari segi positif maupun negatif yang kebanyakan masyarakat pada umumnya tidak mengetahuinya. Sayangnya dalam tulisan Andre Palebangan Bana ini hanya meneliti anak punk secara umum yang sebagian besar punk laki-laki, perempuan punk dilihat sepintas hanya sebagai pacar punk laki-laki, yang disebut dengan istilah betina punk. Sebutan betina ini sangat kasar dan merendahkan kaum perempuan, perempuan punk hanya dianggap sebagai objek laki-laki.

Penelitian juga dilakukan oleh Ricky Sihombing (2009), sebuah tesis S2 STKS Bandung dengan judul penelitian tentang "Tanggapan Masyarakat Terhadap Perilaku Budaya Anak Punk di Kota Medan". Hasil penelitian menemukan bahwa sebagian besar masyarakat berpendapat bahwa perilaku budaya anak punk dinilai kurang menarik dan terkesan negatif. Sebagian besar responden menganggap perilaku punk itu menyimpang dan budaya yang diadopsi oleh anak punk berbeda dengan budaya yang ada pada masyarakat Indonesia pada umumnya. Budaya anak punk adalah budaya jalanan seperti halnya anak jalanan, yang dianggap menyimpang dari norma masyarakat. Punk dianggap sebagai budaya perlawanan terhadap budaya dominan yang cenderung mapan. Dikatakan dalam penelitian ini bahwa perempuan punk yang tergabung dalam komunitas punk ini sangat sedikit, namun merupakan gerakan perempuan yang ingin lepas dari dominasi laki-laki. Hal ini ditunjukkan dengan keinginan mereka membuat film tentang kekerasan terhadap anak perempuan, perkosaan, dan isu tentang perempuan.

Penelitian yang serupa dilakukan oleh Harry Setiawan Burhan (2014) dalam skripsinya di STKS, tentang penerimaan masyarakat terhadap komunitas punk di Aceh. Hasil penelitiannya adalah menggambarkan bahwa masyarakat tidak bisa sepenuhnya menerima komunitas punk, dengan alasan tidak sesuai dengan norma masyarakat dan agama di Aceh, apalagi perempuan punk. Perempuan punk yang berpenampilan aneh cenderung 
urakan sama sekali tidak diterima dalam pandangan masyarakat Aceh, karena dianggap melanggar norma agama dan sosial yang dilekatkan pada perempuan yang harus berpenampilan sesuai kaidah agama Islam yang harus menutup aurat. Dalam penelitian tersebut sangat menarik karena Aceh adalah kota agamis yang cukup ketat menjalankan syariat Islam. Aturan Islam memberi nafas kehidupan masyarakat Aceh, namun masih ada perempuan yang masuk kelompok punk.

Penelitian lain yang agak berbeda, tentang harga diri (self-esteem) komunitas punk dilakukan oleh Andria Yogatama (2013) dalam skripsinya di STKS, melihat punk dari sudut pandang ilmu psikologi. Penelitian ini tentang harga diri yang dimiliki anggota punk dari aspek kekuatan (power), keberartian (significant), kebajikan (virtue), dan kemampuan (competence). Hasil penelitian menunjukkan bahwa anggota komunitas punk ternyata memiliki harga diri tinggi, dengan etos kerja tinggi, mandiri, dan kegiatan yang dilakukan juga positif, hanya saja masyarakat umumnya tidak mengetahui yang mengakibatkan adanya stigma (ciri negatif). Kajian ini melihat sisi positif anak punk yang memiliki kreativitas tinggi di bidang seni yakni musik, menciptakan kaos dan asesoris yang dijual di distro, seni tato dan lain sebagainya. Kajian ini juga menyoroti busana punk yang sudah menjadi trend setter atau fashion ala punk mulai dari baju, jaket, sepatu, dan celana jeans. Penampilan baju perempuan punk dijadikan model yang bisa digunakan oleh kaum remaja perempuan. ideologi punk mulai terkikis oleh budaya kapitalis yang mengadopsi budaya punk untuk dijual sehingga mengaburkan ideologi punk itu sendiri. Banyak remaja perempuan menggunakan busana ala punk hanya sekedar ikut-ikutan tapi tidak tahu ideologi punk. Hal ini mengikis ideologi punk secara pelan-pelan.

Sebuah buku tebal tulisan Kimung pada tahun 2012 tentang punk yang berjudul "Ujung Berung Rebels, Panceg Dina Galur", memberi inspiratif untuk menulis perempuan punk. Tulisan tersebut mengupas tentang musik anak punk yang bernama Rebels, sebuah musik rock legendaris yang merupakan cikal bakal musik punk di Bandung. Musik adalah nafas dan sarana anak punk untuk menyuarakan aspirasinya, melalui musik mereka berkreasi dan ada pesan-pesan yang disampaikan pada pemerintah dan masyarakat. Dalam kelompok musik punk ini, memang sebagian besar adalah punk laki-laki. Posisi perempuan punk di sini hanya sebagai pacar punk laki-laki. Dunia musik memang tidak terlepas dari minuman keras, obat, rokok, dan perempuan. Sebelum pentas mereka menggunakan obat sebagai dopping dan sesudah pentas mereka merayakan dengan perempuan dan minuman keras. Perempuan punk sebagai asesoris pelengkap dalam kehidupan punk laki-laki. Ganti-ganti pasangan adalah hal yang biasa.

Apa yang sudah dibaca dari beberapa tulisan di atas adalah lebih banyak mengupas atau meneliti komunitas punk secara umum. Padahal fenomena perempuan punk ini perlu dikaji karena mereka tidak bisa diterima oleh norma sosial masyarakat dan agama. Namun disisi lain mereka ingin diakui identitasnya dengan melakukan gaya hidup dan penampilan yang berbeda, melakukan gerakan perempuan, ingin keluar dari pusat patriarkat meskipun tetap saja berada di bawah dominasi laki-laki. Sebutan kata betina bagi perempuan punk sangat kasar dan merendahkan kaum perempuan, yang hanya dijadikan objek sex bagi laki-laki. Fenomena yang tidak kalah menarik adalah busana perempuan punk jadi trend setter fashion bagi remaja perempuan.

Hubungan tulisan yang sudah dilakukan tersebut dengan tulisan yang akan saya lakukan ini adalah ingin melengkapi data perempuan punk tentang identitas dan gaya hidup perempuan punk, barangkali bisa menjawab siapa dan 
bagaimana perempuan punk ini. Beberapa bahan bacaan lebih banyak mengungkap komunitas Punk, namun minim tulisan secara khusus tentang perempuan punk, padahal mereka memiliki gaya penampilan tersendiri.

\section{HASIL DAN BAHASAN 1.Komunitas Punk Ujung Berung}

Komunitas punk banyak ditemui di Ujung Berung Bandung, bahkan menurut sejarah di lokasi tersebut awal tumbuhnya punk di Bandung. Ujung Berung sangat padat penduduknya dan cukup ramai, karena kawasan ini tidak terlalu jauh dari pusat kota. Tipikal masyarakat agraris dan ditunjang dengan kedekatan Ujung Berung dengan pusat pemerintahan membuat kawasan ini kaya akan potensi kesenian. Tercatat puluhan seni tradisional yang hadir di Ujung Berung antara lain seni benjang yang sangat terkenal di Bandung, kuda lumping, kecapi suling, angklung, pencak silat, dan lain-lain.

Lalu satu seni muncul berkembang di tahun 1980-an adalah musik metal underground yang sangat digandrungi kaum muda untuk menyampaikan hasrat ketidakpuasan terhadap pemerintah melalui lirik musik. Menurut Kimung ( 2012: 23). Ujung Berung Rebels adalah grup musik rock terkenal yang memiliki ciri atribut sendiri layaknya sebuah komunitas punk yang memiliki label rekaman sendiri, fashion, bahasa prokem atau slang, jaringan distribusi, dan jauh dari tangan kapitalis yang mengeksploitasi mereka. Prinsip "do it your self" dan dekat dengan true spirit melahirkan budaya perlawanan terhadap budaya dominan.

Pada akhirnya Ujung Berung sekarang, tumbuh komunitas punk yang tersebar di berbagai kelurahan di Ujung Berung, mereka tinggal dengan menyewa rumah atau indekos seperti di daerah Cilengkrang, Cigending, dan Gunung Sembung. Kehidupan sehari-hari bekerja di sektor informal, mengamen, membuat sablon baju, berdagang atribut punk (kaos, bandana, asesoris), tapi ada juga yang bekerja di perusahaan tapi prosentasenya kecil seperti pegawai toko dan pabrik. Setiap malam minggu atau libur dan ada even musik, mereka keluar dan berkumpul untuk kebersamaan dan mencari kebebasan seperti di cafe, alun-alun, perempatan jalan, dan lapangan terbuka.

Punk pertama kali muncul di Inggris pada tahun 1970 (Suwardi, 2011: 224), berawal dari kumpulan anak muda di London. Kelompok ini kebanyakan dari anak-anak kelas pekerja yang sudah terbiasa dengan kerasnya kehidupan di London, dengan penampilan yang lusuh, sepatu boots, rantai, spike, jaket kulit, dan celana jeans yang ketat dan komunitas punk ini lebih sering di jalan. Pertengahan tahun 1970, salah satu anggota punk mempunyai inisiatif untuk membuat sebuah group band, karena mereka beranggapan dengan musik bisa menyampaikan suara-suara perlawanan terhadap pemerintah Inggris saat itu. Group band ini bernama Sex-Pistols yang didirikan oleh Sid Vicous. Tahun 1980, punk mulai merambah Amerika Serikat dan bermunculan aliran punk yang lain seperti punk rock dan punk hardcore, akan tetapi mereka tetap memegang teguh ideologi anarkisme dan anti pemerintah. Punk rock dikenal lebih urakan dengan busana yang lusuh robek dan rambut gaya mohawk.

Tahun 1990 punk mulai masuk ke Indonesia dan punk masuk di Bandung melalui akses kaset, $\mathrm{CD}$, dan internet. Di Indonesia, punk dianggap sebagai gerombolan remaja berperilaku nyeleneh atau sekedar group band yang vokalisnya tidak jelas. Demikian pula di Bandung, tepatnya di Ujung Berung terdapat komunitas punk, mereka membentuk group band bernama Rebels yang cukup dikenal di Bandung. Anggota punk di Ujung Berung sebagian besar adalah lakilaki, barangkali dunia punk adalah dunia yang keras, cenderung brutal, bebas, dekat dengan narkoba, lusuh, dan stigma lainnya sehingga perempuan enggan ikut dalam komunitas punk tersebut. Oleh karena itu 
tidak banyak perempuan yang masuk dalam komunitas punk, karena pada umumnya perempuan senang dengan keindahan, kebersihan, kecantikan, dengan berpenampilan elegan, tidak seronok, dan terlihat feminim.

Secara sosial, perempuan sering diposisikan sebagai objek dan atraktif tidaknya seorang perempuan menjadi sangat tergantung pada definisi yang ditetapkan oleh laki-laki. Perempuan cenderung menjadikan tubuhnya sendiri sebagai objek untuk mencapai kategori atraktif semacam cantik, menarik, langsing, manis atau putih. Perempuan diajak untuk selalu melakukan observasi terhadap tubuhnya sendiri dan memastikan bahwa mereka melakukan hal yang tepat seperti yang diharapkan dan diangankan oleh kaum laki-laki. Industri kecantikan dan fashion sering mengajak perempuan untuk menikmati proses observasi dan olah tubuhya sebagai objek fetish (sesuatu untuk memuaskan hasrat). Perempuan diajak untuk menikmati dan bangga dengan posisinya sebagai objek tatapan, ketika banyak mata menatap kagum pada penampilan. Sebuah survei dilakukan oleh Majalah Redbook terhadap 100 orang laki-laki. Survei tersebut meminta laki-laki untuk memberikan penilaian terhadap cara berpenampilan perempuan. Sebagian besar laki-laki tertarik saat melihat perempuan yang menggunakan busana kasual kaus atau tank top putih dengan celana jeans. Tertarik busana yang memperlihatkan lekuk tubuh perempuan yang identik dengan bentuk tubuh yang indah. Perempuan berdandan tipis dan natural justru bisa membuat laki-laki merasa penasaran dan membuat perempuan tidak membosankan untuk dilihat. Laki-laki juga menyukai perempuan yang tampil dan dandan dengan terlihat sedikit berantakan tapi sexy. Memang pada dasarnya perempuan diciptakan dengan kelembutan dan keindahan, laki-laki mengatakan bahwa sangat senang bila melihat perempuan yang memakai pakaian girly, rambut ikal, panjang dan hitam.
Itu pandangan umum laki-laki terhadap perempuan yang dianggap gender normatif di bidang penampilan, fashion (termasuk clothing dan aksesoris) dan tata rias muka maupun rambut. Perempuan punk melawan pandangan umum tersebut, karena mereka memiliki gaya hidup atau style penampilan yang memiliki fungsi dan simbol tertentu. Menurut Irwan Abdullah (2006: 102) sebagaimana yang dikatakan oleh George Simmel, mengatakan bahwa ide fashion didasarkan pada suatu prestise dan identitas kelompok. Fashion dipandang sebagai mode, apabila telah diadopsi dan diterima sekelompok masyarakat untuk meningkatkan prestise dan membentuk identitas kelompok. Mode dianggap sebagai suatu gaya hidup atau style yang memiliki fungsi dan simbol masyarakat tertentu. Demikian pula kelompok perempuan punk memiliki fashion sendiri untuk membentuk identitas kelompoknya.

\section{Lima Perempuan Punk di Ujung Berung}

Hasil wawancara terhadap lima perempuan punk di Ujung Berung, mengatakan bahwa mereka menjadi punk karena pergaulan teman, perceraian orang tua, ekonomi keluarga, dan lingkungan atau pergaulan yang mempengaruhi mereka memilih gaya hidup punk. Mereka nyaman dengan hidup yang dijalani, mandiri, tidak peduli dengan kritikan orang, dan bebas berekspresi melalui seni atau hasil karya yang dibuat sendiri (kaos, musik, dan tato) serta melakukan kritik sosial pada pemerintah. Pengaruh musik dan ideologi punk menjadikan perempuan punk ini lebih berani, kuat, dan mandiri.

Kelima perempuan punk Ujung Berung ini semua mengatakan bahwa mereka tidak diterima di lingkungan keluarganya, bahkan orang tuanya mengusir dan menganggap bukan anaknya. Keluarga tidak mengakui dan merasa malu punya anak seperti mereka. Masyarakat sekitar juga tidak menerima perilaku dan penampilan mereka yang dianggap kotor, 
kucel, tidak umum, pembuat onar, pemabuk dan stigma lainnya. Namun, mereka tidak peduli dan tidak ambil pusing, prinsipnya asal tidak merugikan dan mengganggu orang lain, maka tetap menjalani kehidupannya. Kelima perempuan punk ini tinggal berdekatan dengan menyewa kamar atau kos di daerah Cijambe Ujung Berung, awalnya kelompok kecil ini merintis kegiatan menyablon kaos punk lalu ikut kelompok musik punk sebagai suporter jika musik ini pentas. Musik dianggap sebagai media mereka untuk berkumpul, berekspresi, dan menyuarakan ideologi mereka tentang kebebasan dan kritik sosial. Bagi mereka, komunitas punk adalah orang mandiri, gigih, dan kreatif, itu sebabnya mereka hidup mandiri lepas dari orang tua dan bekerja apa saja untuk menyambung hidup. Seperti filosofinya do it yourself adalah filosofi punk, hidup mandiri lepas dari orang tua dan mengerjakan sendiri semua hal seperti membuat baju, topi, tas, tato, tindik, dan lain-lain.

Tinggal di rumah kontrakan kecil atau indekos dan tempat mangkal anak punk, sering mendapat cibiran dan penolakan dari masyarakat. Memang diakui ada orang yang berpenampilan punk sering melakukan tindakan kriminal dan mabuk, ini mengakibatkan adanya stigma dari masyarakat. Banyak orang yang bergaya seperti punk tapi menyalahgunakan dandanan punk ini untuk bertindak kriminal, seperti mabuk, ngompas, dan kriminal lainnya. Menurut kelima informan ini, mereka tidak pernah melakukan kriminal, hanya menegak minuman keras tapi tidak sampai mabuk dan mengamuk. Minuman keras yang dikonsumsi memiliki kadar alkohol rendah hanya untuk hiburan, tidak sampai memabukkan. Minuman keras dibeli secara patungan dan diminum bersama pada saat mereka lagi santai dan berkumpul bersama.

Dilihat dari tingkat pendidikan, ke lima informan hanya lulus SLTP dan tidak melanjutkan ke SLTA, karena alasan ekonomi, tidak mau belajar lebih senang hidup bebas, mau mandiri, ikut teman punk, dikucilkan keluarga dan orang tua. Mereka berusia antara 15 sampai 25 tahun, usia muda bahkan ada yang masih belasan tahun yang harusnya masih duduk di bangku sekolah. Salah pergaulan dan kurangnya perhatian orang tua, merupakan faktor utama mereka tidak melanjutkan sekolah dan masuk komunitas punk. Masa remaja merupakan masa pencarian identitas, dan pada masa itu pengaruh teman sangat kuat. Masa remaja lebih banyak berada di luar rumah bersama temannya atau kelompoknya, sehingga pengaruh teman sebayanya ini sangat kuat dan lebih besar daripada keluarganya.

Demikianlah penelitian ini melibatkan lima informan perempuan punk, yang dipilih berdasarkan sejauhmana mereka mengerti dan terlibat langsung dengan objek penelitian, yakni bagaimana mereka mengekspresikan penampilannya sebagai identitas dan gaya hidupnya.

\section{a. Icha}

Dalam hal penampilan, perempuan punk mempunyai gaya hidup tersendiri, sebut saja Icha gadis berusia 18 tahun ini memilih pakaian atau asesoris yang nyaman dipakai, tidak tergantung dengan tren mode sekarang dan ingin mengekspresikan gaya yang berbeda dengan orang lain. Meskipun Icha menggunakan asesoris punk dan warna rambut mencolok. Namun ia tidak mengharuskan tampilannya selalu seperti itu, ia mengkombinasikan dengan berbagai asesoris lainya agar terlihat nyaman dipakai dan tidak berlebihan. Hanya saat tertentu jika ada pentas musik mereka memakai pakaian gaya punk. Icha adalah perempuan yang memberontak dan ingin bebas untuk berekspresi. Icha berasal dari keluarga yang tidak utuh, bapaknya meninggal dunia dan ibunya menikah lagi, sejak kecil ikut neneknya karena orangtuanya berpisah. Icha mengenal punk sejak bangku SMP dari pergaulan temannya. Kehidupannya yang memilih 
untuk bergaya hidup punk mengalir dengan sendirinya tanpa direncanakan. Menurutnya bergaya hidup punk adalah suatu kebebasan dan pemberontakan untuk berekspresi. Icha merasa nyaman dan senang berpakaian punk seperti itu, seperti yang dikatakan sebagai berikut:

"dengan berpakaian punk ada rasa percaya diri (pede), timbul kekuatan dan semangat. Rasanya seperti bebas, seperti punk laki-laki. Kalau laki-laki mampu kenapa perempuan tidak. Gua juga bisa dan berani kok berpakaian punk."

Cara berpakaian seperti itu, tentu saja sering mendapat cibiran, oleh masyarakat dianggap aneh dan suatu ancaman. Saat masyarakat bertemu dengan mereka selalu memalingkan muka dan memandang negatif. Sikap masyarakat ini ditanggapi oleh Icha sebagai hal yang biasa tidak perlu dipermasalahkan dan tidak ambil pusing. Seperti penuturan Icha berikut ini :

"Masyarakat dan tetangga sering menganggap rendah penampilannya, kucel, kotor, bau, dan aneh. Memang pakaiannya kadang dipakai beberapa hari, tidak ganti atau dicuci. Apalagi sering duduk dan tiduran di jalan atau emperan toko, jadi cepat kotor dan bau. Tapi saya gak peduli cibiran orang. "

Icha, akhirnya keluar dari rumah dan menikah muda dengan teman laki-laki punk juga. Mereka hidup dengan mengontrak satu kamar di Ujung Berung dengan harga 200 ribu rupiah per bulan. Untuk hidup sehari-hari mereka mencari makan dengan mengamen di perempatan jalan Ujung Berung. Hanya malam minggu dan liburan mereka berkumpul dengan sesama punk. Minuman keras dan merokok adalah hal yang tidak bisa dipisahkan komunitas punk. Harga sebotol minuman keras 50 ribu rupiah yang dibeli dengan iuran bersama temannya. Menurutnya tidak sampai mabuk, karena dia harus bekerja mengamen mencari uang. Kalaupun mabuk, maka ditolong temannya diantar ke tempat kontrakan. Solidaritas sesama punk sangat tinggi, mereka saling bantu dan menolong jika ada teman yang sakit atau mengalami musibah.

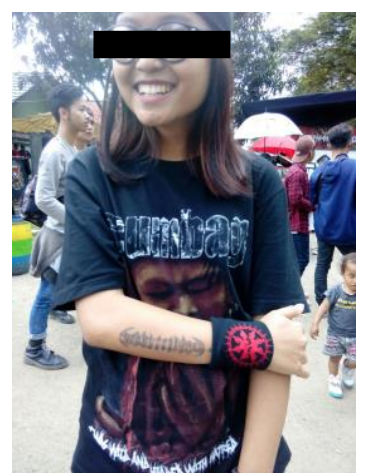

Gambar 1. Icha, Punk Ujung Berung Sumber: Ani, 2017.

\section{b. Rita}

Selain Icha ada Rita yang berpenampilan lebih berani yakni gaya rambut mohawk pada saat ada even tertentu misalnya ada pertunjukan musik band, tapi dalam keseharian menggunakan pakaian sederhana dan rambut biasa. Menurutnya punk memang identik dengan rambut mohawk, tapi seiring berjalannya waktu tidak dipakai lagi karena agak repot bagi perempuan. Biasanya laki-laki punk yang sering menggunakan model rambut mohawk. Ketertarikan gaya hidup punk terletak pada kebebasan dalam bermusik, pola pikir dan gaya yang menurutnya nyaman. Rita yang berusia 23 tahun ini tipe perempuan yang mandiri tidak suka diatur dan diperintah orang lain. Demikian pula dalam berpenampilan, Rita sangat berani tampil beda yakni mengubah rambutnya bergaya mohawk dan dicat warna warni. Menurutnya punk adalah paham kebebasan untuk berekspresi dan lebih berani asal tidak merugikan orang lain. Kebebasan yang dianutnya asal bertanggung jawab untuk diri sendiri dan menghasilkan kreativitas. Tapi itu dahulu, sekarang model rambut mohawk tidak lagi digunakan oleh kaum perempuan punk, alasannya cukup sulit dan memakan waktu lama. Sebagai gantinya rambut hanya di cat warna warni dan menggunakan kalung, anting, ikat pinggang logam sebagai asesorisnya. Asesoris logam 
merupakan simbol kejantanan dan jika dikenakan perempuan dianggap macho. Adapun sepatu booth yang dikenakan adalah simbol ketahanan diri bagi seorang punk. Sepatu booth biasa digunakan pekerja proyek dan kaum buruh untuk bekerja keras, berjalan di lumpur, becek, air, api dan lain sebagainya. Jadi sepatu booth dianggap sebagai simbol ketahanan diri seseorang dari segala gangguan dan mara bahaya.

Cat rambut warna-warni memang menjadi kekhasan bagi perempuan punk, mereka mengecat dibantu secara bergantian dengan temannya. Hanya perlu uang $\mathrm{Rp} 20.000,00$ untuk membeli cat rambut dengan warna kesukaannya, biasanya berwarna kuning keemasan. Untuk memotong rambut juga dilakukan sendiri, mereka tidak mau pergi ke salon sesuai filosofinya mandiri dan semua harus dikerjakan sendiri bersama temannya. Seperti yang diungkapkan Rita berikut ini:

"Dengan ngumpul bareng, kita sering ngecat dan motong rambut bergantian. Gak pernah pergi ke salon, paling beli peacok pewarna rambut harga 20 ribu. Rambut di cat sebulan sekali, biar terlihat lebih modis dan gaya. Kalo rambutnya hitam kesannya kurang keren dan tidak pede."

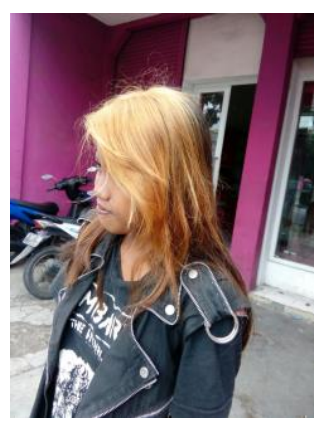

Gambar 2. Rita, dengan Cat Rambut Sumber: Ani, 2017.

\section{c. Cessa}

Informan lain adalah Cessa. Wanita yang menikah dan punya satu anak ini adalah informan yang paling berani dan lebih mementingkan diri sendiri. Cessa punya tato dan tindik di hidung untuk menonjolkan bahwa dia seorang punk. Tato dimaknai sebagai suatu karya seni dan identitas diri yang lebih spesifik dan merupakan simbol perjalanan hidup yang dituangkan di media kulit berbentuk bayi bersayap. Katanya pernah memiliki anak tapi meninggal dunia saat melahirkan dan suaminya pergi begitu saja. Selain tato, Cessa memakai celak alis dan mata sebagai pelengkap identitas punk. Tato bagi Cessa buka hanya sekedar seni saja tapi memiliki makna yang menceritakan kisah hidupnya dan dia itu pribadi seperti apa. Seperti yang diungkapkan Cessa berikut ini:

"Kalau untuk saya sih tato itu menceritakan kisah hidup saya dan saya ini pribadi seperti apa. Tato memiliki aturan tertentu, kalau tatto sebelah kanan tangan harus bergambar baik karena berepengaruh pada pola hidup yang baik misalnya bunga, malaikat, dewi dan sebelah kiri bisa bergambar jelek misalnya serigala, iblis, setan, serigala."

Tato biasanya dilakukan di tempat komunitasnya jadi tidak membayar, namun ada juga dilakukan di luar komunitas dengan cara membayar. Perhitungannya adalah per centimeter Rp 20.000,00 sampai Rp30.000,00 tergantung dari tingkat kesulitannya. Misalnya panjang $10 \mathrm{~cm}$ dan lebar $15 \mathrm{~cm}$, maka menjadi $25 \mathrm{~cm}$, sehingga harga yang harus dibayarkan $\mathrm{Rp}$ 500.000,00. Bagi Cessa, tato memiliki makna tersendiri seperti yang diceritakan berikut ini:

"Tulisan Carnesia yang ada di tangan kanan ini adalah nama anak saya yang selalu menemani dan membawa keberuntungan buat saya. Sedangkan gambar serigala di tangan kiri saya menggambarkan saya seorang pemberani siap berperang melawan musuh paling depan, karena hewan jenis anjing ini garang pemberani tapi sangat setia. Adapun kalung di serigala ini merupakan kalung Indian sebagai tanda pengusir mimpi buruk dan membawa keberuntungan. Namun ada juga pantangan gambar bunga, bagi seorang perempuan disarankan jangan disebelah kanan, karena kalau tidak 
kuat menjaga dirinya maka dia bisa menjadi liar tidak terkendali. Tato itu berpengaruh pada hidup seseorang".

Tatto, bagi komunitas punk memiliki aturan dan makna tersendiri. Tidak sembarangan melukis dan meletakkan tato di tangan atau kaki karena tato berpengaruh pada hidup seseorang. Sebelah kanan harus lukisan yang baik dan sebelah kiri bisa lukisan jelek. Namun ada pantangan juga jika bunga sebaiknya dilukis tidak sebelah kanan, karena ada kepercayaan jika tidak kuat menjaga dirinya maka menjadi liar dan binal. Sebaliknya tato dipercaya membawa berkah keselamatan dan merupakan gambaran pribadi pemiliknya. Sebagai contoh serigala sebagai simbol hewan setia sekaligus pemberani melawan musuh di garis depan, artinya perempuan punk ini berani melawan ketidakadilan dan diskriminasi serta dominasi yang dilakukan oleh para lelaki dan pemerintah yang zalim.

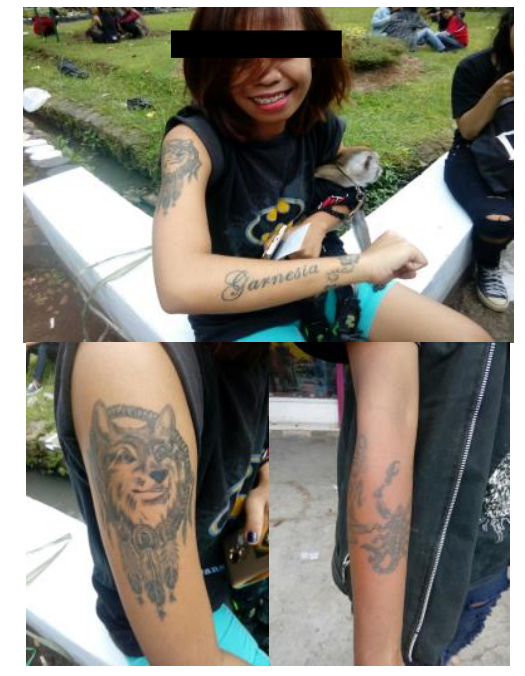

Gambar 3. Cessa, dengan Tato Sumber: Ani, 2017.

\section{d. Zizi}

Zizi, gadis belia berusia 15 tahun ini baru duduk di bangku SMP kelas 2. Baru setahun bergabung menjadi komunitas punk bersama dengan pacarnya yang masih duduk di bangku SMA. Alasan ikut punk adalah karena ikut-ikutan temannya, lama kelamaan dirasa hidup enak bebas maka sering membolos sekolah dan mendapat marah orang tuanya. Lalu diusir dari rumah dan kini hidup bersama neneknya yang tetap memberi kasih sayang. Baginya dunia sekolah sangat membosankan dan tidak bebas, banyak kegiatan dan aturan, sehingga Zizi memilih punk sebagai pelarian untuk mencari kebebasan. Meskipun masih sekolah, tapi Zizi sudah tidak merasa nyaman dan jika sewaktu-waktu dikeluarkan dari sekolah sudah siap. Teguran dan marah sering didapat dari gurunya, tapi Zizi tetap membandel bahkan sekarang sudah memakai tindik di lidah dan gusi. Di kalangan komunitas punk, melakukan tindik di gusi dan lidah adalah suatu keberanian untuk menahan rasa sakit. Degan alat sederhana yakni sebuah jarum dibakar agar steril, lalu ditusukkan begitu saja di kulit. Awalnya sakit bengkak selama 2 atau 3 hari, lalu lama-lama sembuh dan tidak merasakan sakit. Keberanian mereka melakukan tindik ini dianggap sebagai simbol kuat menahan rasa sakit. Hidup di dunia ini sangat keras, itu sebabnya mereka harus kuat menahan rasa sakit baik yang disebabkan oleh ekonomi, sosial budaya dan politik.

Selain di mulut dan gusi, tindik bisa dilakukan di mana saja seperti hidung, telinga, pusar, bahkan di kelamin. Menurut pengakuan informan, seorang temannya punya tindik di alat kelaminnya, ini merupakan simbol seksualitas mereka. Namun hal ini jarang dilakukan, mereka lebih banyak menindik di telinga dengan lubang yang makin lama makin besar. Caranya, telinga yang sudah ditindik diberi sedotan kecil dan lama kelamaan lubang itu membesar dan diberi dengan uang logam. Berikut ini diungkapkan oleh Zizi yang memiliki tindik di mulut, dan gusi.

"Awalnya coba-coba untuk menindik di hidung dan telinga. Lalu kena marah guru di sekolah. Agar tidak kelihatan, maka menindik di lidah dan gusi. Lagipula menindik di hidung dan telinga sudah biasa dilakukan orang, tapi 
kalau dilakukan di lidah dan gusi lebih keren. Tidak semua orang mau menindik di lidah dan gusi, karena takut sakit dan bahaya. Ku sih gak takut, karena pacar juga menindik di lidah dan gusinya gak terjadi apaapa. Paling sakit dikit gak mau makan. Menindik dilakukan sendiri sama pacar, dengan jarum yang udah dibakar, katanya biar steril. Serem sih yang melihatnya, tapi setelah itu biasa saja tuh."

Selain di gusi dan lidah, tindik dilakukan di telinga dan biasanya oleh punk laki-laki. Tindik telinga dilakukan dengan cara yang sama yakni menggunakan jarum yang dibersihkan dengan alkohol dan dibakar biar steril. Lalu lubang tusukan dimasuki semacam sedotan agar terbentuk lubang anting. Beberapa hari kemudian jika sakitnya hilang, sedotan diambil lalu dimasuki plug yakni sebuah anting berbentuk lingkaran besar terbuat dari titanium, tulang atau acrylic. Lubang telinga makin lama makin besar, yang tadinya ukuran lingkaran $5 \mathrm{~mm}$ menjadi $5 \mathrm{~cm}$.

Menurut Zizi menindik di lidah dan gusi gampang-gampang susah, kalau tidak tahu caranya dan tidak steril bisa menyebabkan bengkak, infeksi dan pendarahan. Pengetahuan menindik didapat dari teman sesama punk, mereka secara bergantian melakukan tindik. Kalau kurang pengalaman dan pengetahuan, maka terjadi infeksi bengkak atau pendarahan. Penuturan Zizi berikut ini:

"Jika ditindik oleh orang yang kurang pengalaman, akan terjadi pendarahan. Menurut dokter, katanya terkena pembuluh darah vena sehingga luka. Diopname tiga hari dan yang membiayai teman punk sendiri, keluarga dan orang tuanya tidak ada."

Bagi Zizi, melakukan tindik atau piercing itu bukan sekedar gaya melainkan sebagai simbol berani menahan rasa sakit dan tidak takut bahaya. Hidup ini kadang susah kadang senang, pahit dan manis, mulus dan ada godaan, itu sebabnya mereka harus kuat dan tidak takut hidup susah sakit dan bahaya. Semua itu harus dihadapi dengan ikhlas, sabar dan kuat.

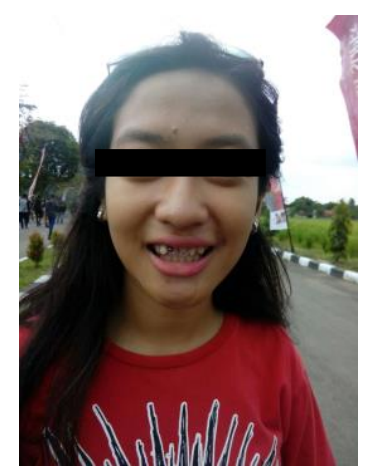

Gambar 4. Zizi, dengan Tindik Lidah dan Gusi Sumber: Ani, 2017.

\section{d. Deisa}

Deisa adalah perempuan punk berusia 22 tahun, memiliki seorang anak berusia balita. Deisa berasal dari keluarga yang broken, orang tuanya bercerai dan sejak itu Deisa kecil ikut bibinya. Bibinya bekerja di pasar sebagai pedagang sayur yang pendapatannya hanya cukup untuk makan sehari-hari. Deisa membantu bibinya di pasar dan hanya menamatkan sekolah sampai SLTP. Mengenal dunia punk, saat Deisa mengenal temannya yang mengajak melihat konser musik di Tegallega Bandung. Pertemanan ini akhirnya membuat Deisa melangkah lebih jauh pada pergaulan bebas, sampai akhirnya hamil di luar nikah dengan seorang punk juga. Mengetahui hamil, bibinya marah dan mengusir dari rumah. Deisa lalu kos bersama kekasihnya, beruntung kekasihnya bertanggungjawab dan menikahinya. Sehari-hari suaminya bekerja sebagai pedagang asesoris punk di Pasar Ujung Berung, sedangkan Deisa membuat sablon kaos di rumah petaknya.

Sehari-hari penampilan Deisa memakai jeans belel, jaket, dan rantai gelang. Kalung dan rantai gelang tidak pernah lepas dari penampilannya, menurutnya ini sangat penting bagi dunia punk yakni merupakan simbol solidaritas dan persatuan sesama punk. Masyarakat 
sering menganggap punk hanya sampah dan dinilai menyimpang oleh masyarakat, oleh karena itu mereka membuat komunitas yang memiliki rasa solidaritas dan kesetiakawanan tinggi sebagai tempat perlindungan. Deiza mengatakan bahwa gelang dan ikat pinggang rantai yang dikenakan adalah simbol persatuan dan mereka tidak mau dikekang atau dirantai oleh belenggu aturan. Cerita Deiza berikut ini:

"Gue suka banget dengan ikat pinggang dan gelang rantai, karena ini menunjukkan bahwa kami ini tidak mau dikekang oleh aturan yang ketat dan berlebihan. Kami harus bersatu dan memiliki kebersamaan sesama punk untuk melindungi diri dari anggapan masyarakat dan keluarga yang negatif, padahal tidak semua punk jelek. Kami hanya ingin hidup bebas mandiri tapi tidak melakukan kriminal dan tidak melanggar hukum, bahkan kami berkreativitas. Biasanya hanya oknum yang mengaku dan bergaya punk lah sering membuat onar dan kriminal. Selain senang menggunakan asesoris rantai, saya juga sering mengenakan baju mini dan kaos warna hitam dengan berbagai emblem yang menempel di baju. Warna hitam merupakan simbol keberanian untuk tidak mau ditindas, sedangkan emblem adalah kain bekas yang dirapihkan dan disablon dengan gambar group band lalu ditempelkan pada kaos".

Menurut Deisa, kaos yang sering digunakan anak punk adalah hasil modifikasi. Ada tiga cara memodifikasi, kaos yang sering digunakan para punkers. Pertama, kaos hitam yang dibeli disablon sendiri dan diberi gambar grup musik punk atau tulisan bertema sosial. Kedua, menyobek-nyobek beberapa bagian kaos sampai terlihat berbeda dan unik. Ketiga, kaos diberi tambahan seperti peniti, emblem, pin, rantai, dan lain-lain.

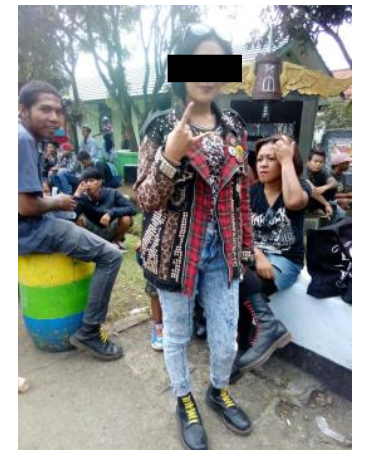

Gambar 5. Deisa, dengan Gaya Punk Sumber: Ani, 2017.

Demikianlah, kelima perempuan punk Icha, Rita, Cessa, Zizi, dan Deisa, merupakan gambaran perempuan yang memegang kebebasan berekspresi melalui penampilan. Fashion perempuan punk merupakan wujud eksistensi kehadiran mereka dan simbol perlawanan terhadap budaya berpakaian dominan. Perlawanan yang dimaksud adalah melawan sikap pasif dan konsumtif. Untuk melawan dominasi kapitalis dan budaya patriarkat yang telah mengekang kebebasan termasuk berpenampilan. Mereka biasanya menggunakan rok mini, sepatu booth, jaket spike, rambut mohawk, stocking, anting atau tindikan, tato, piercing, rantai, celana jeans sobek, jaket kulit, jaket jeans dan pin emblem, semuanya mengacu pada makna perlawanan dalam hal kebebasan berpenampilan.

\section{Makna Penampilan dan Fashion}

Kelima informan di atas memiliki penampilan dan fashion yang sama, bahkan semua mengecat rambutnya dengan warna kuning keemasan, dengan alasan ingin tampil beda. Hanya saja, Zizi dan Cessa lebih berani dan ekstrim yakni menindik di guzi, lidah dan tato. Bahkan Icha juga dulu pernah bergaya mohawk yakni rambut yang berbentuk duri mendongak ke atas sebagai simbol menentang penguasa yakni anti penindasan yang zalim. Mohawk adalah rambut suku Indian yang bernama mohican. Rambut dibuat kaku ke atas yang tidak mudah layu sebagai simbol perlawanan bagi kaum tertindas yang tidak terima posisi mereka 
di bawah. Punk menganggap strata mereka adalah "takdir" yang dapat dilawan dan mereka mampu mengatasi takdir itu dengan bermusik. Jeans robek yang digunakan informan sebagai simbol kemerdekaan gerak dikarenakan ruang gerak mereka dibatasi dan terhimpit oleh lingkungan. Cessa yang penuh tato di tubuhnya yakni bergambar serigala, bunga, malaikat, tengkorak, salip, dan api dalam tubuhnya sebagai simbol kekuasaan atas tubuhnya dan rasa cita rasa seni yang dimiliki. Menurut Cessa mau diapain tubuhnya terserah dia karena tubuhnya adalah miliknya sendiri. Tato menceritakan kisah hidupnya dan menunjukkan siapa dia. Adapun rantai yang dipakai Deisa dianggap sebagai simbol kesatuan dan kebersamaan sesama punk, tidak ada diskriminasi dan perbedaan agama, ras, maupun ekonomi. Mereka adalah sama, senasib seperjuangan, suka duka bersama dan saling membantu. Rasa kebersamaan dan solidaritas inilah yang menjadi alasan kuat Deisa dan teman-temannya masuk dalam komunitas punk. Seperti yang diungkapkan oleh Deisa:

"Punk is the only solid in very human. Solidaritas mereka saja sih yang aku dalami dan sejarah tentang punk yang sampai sekarang masih diabadikan. Punk bagi saya sangat mandiri dan membuat saya bisa melihat dunia luar. Bagaimana merasakan pahit, panas, dingin, sakit, lapar tidak bisa makan. Adakah yang peduli pada saya saat seperti itu? Saya merasa jika ada punkers lain adalah teman atau saudara bagi kita semua, jika ada yang sakit kesusahan kita bantu, ibarat sepiring berdua."

Adapun tindik adalah sebagai simbol penguasaan penuh pada tubuhnya sendiri, karena tindik menimbulkan rasa sakit maka makna yang terkandung adalah kita harus kuat bisa menahan dari rasa sakit dan segala rintangan hidup. Jangan takut sakit dan bahaya, semua bisa diatasi kalau kita kuat. Sedangkan celak atau eye shadow hitam di mata sebagai simbol masa depan yang suram dan tidak menjajikan, namun mereka siap untuk jadi orang bawah sampai akhir hidupnya. Mereka juga suka mengenakan baju, kaos, sepatu, rompi, dan bandana warna hitam. Warna hitam adalah simbol kegelapan dan kesuraman, orang bawah tanah namun harus kuat, mandiri, dan berani. Sedangkan sepatu booth yang biasa dipakai oleh prajurit biasanya digunakan di medan sulit, berbatu, dan licin, sebagai simbol bahwa punk akan siap menghadapi rintangan apapun baik sosial hukum maupun ekonomi.

\section{PENUTUP}

Semua atribut yang dikenakan dalam penampilan 5 (lima) perempuan punk yakni Icha, Rita, Zizi, Cessa, dan Deisa ini merupakan representasi perempuan punk sebagai bentuk perlawanan terhadap gender normatif. Gender normatif adalah penguatan terhadap peran norma yang harus diambil laki-laki dan perempuan di masyarakat (Nursyahidah, 2016: 112). Peran gender memperkuat gender normatif atau gender normatif ini menekan laki-laki dan perempuan untuk bertindak sesuai dengan peran gendernya. Jika tidak sesuai dengan dengan peran gendernya, maka dianggap sebagai perlawanan terhadap gender normatif.

Pada konteks itu, perempuan punk menunjukkan keinginan lepas dari norma sosial dan standar ideal femininitas. Mereka lepas dari norma sosial yang memperkuat atau memaksa standar ideal dari kefeminiman. Mereka tidak menganut budaya patriarki, karena apa yang dilakukan oleh laki-laki mereka juga bisa melakukan. Jenis kelamin bukan jadi masalah bagi kaum punkers, sehingga perempuan punk menjadi lebih bebas berpenampilan karena gender normatif tidak mempengaruhi kehidupannya yang akhirnya merubah mereka menjadi berkuasa pada tubuhnya. Perempuan punk merasa tidak bersalah atau menjadi korban dari proses objektivikasi dan pendewaan 
tubuh dianggap sebagai bagian dari kemandirian seorang perempuan. Pada titik ini perempuan punk seolah sebagai agensi bebas yang ingin berekspresi menarik untuk memuaskan diri sendiri, bukan untuk memuaskan laki-laki.

Berbeda dengan perempuan kebanyakan yang ingin tampil sesuai dengan gender normatifnya. Jadi seolah ada transformasi dari objek laki-laki menjadi subjek laki-laki. Tak heran, jika perempuan punk ini menjadi percaya diri dan sering mencantumkan atribut-atribut yang menandai atrakstivitas fisiknya, yang sebetulnya bias dengan tatapan laki-laki. Perempuan punk mencoba tidak memperdulikan stigma sosial tentang penampilannya bahwa perempuan harus girly, anggun, cantik, natural, halus dan lain sebagainya. Perempuan punk menggunakan atribut penampilan sebagai simbol yang mempunyai makna perlawanan, melalui pakaian, make up, rambut, dan asesoris pada tubuhnya. Dalam estetika punk, mereka berupaya untuk menghilangkan diri dari budaya dominasi dan gender normatif yang diresepkan. Mereka keluar dari pusat patriarki dan menentang ide-ide feminitas. Perempuan punk memiliki pengalaman dan relasi gender yang berbeda dengan kaum perempuan umumnya, hal ini bisa dilihat dari gender acts (estetika gender). Perempuan punk menampilkan gender acts secara subyektif yang tidak tunduk pada aturan sosial sebagai identitasnya.

\section{DAFTAR SUMBER}

\section{Makalah, Laporan Penelitian, Skripsi, Tesis, dan Jurnal}

Palebangan Bana, Andre. 2007. Punk Ujung Berung. Skripsi S2. Bandung: STKS.

Sihombing, Ricky. 2009. Tanggapan Masyarakat terhadap Perilaku Budaya Anak Punk di Kota Medan”. Skripsi. Bandung: STKS.

Setiawan Burhan, Harry. 2014.
Penerimaan Masyarakat terhadap Komunitas Punk di Aceh. Skripsi. Bandung: STKS.

Yogatama, Andria. 2013.

Harga Diri (self-esteem) Komunitas Punk di Dago. Skripsi. Bandung: STKS.

Ari Prasetyo, Frans. "Punk: Sub Kultur Kaum Muda Perkotaan dan Lintasan Transnasional". Makalah dalam Seminar Punk, Penentangan dan Politik Transnasionalisme. Bandung, 24 Januari 2017.

\section{Buku}

Abdullah, Irwan. 2006.

Dinamika Masyarakat dan Kebudayaan Kontemporer. Yogyakarta: TICI Publications.

Abdullah, Irwan. 2015.

Kontruksi dan Reproduksi Kebudayaan. Yogyakarta: Pustaka Pelajar.

Agger, Ben. 2014.

Teori Sosial Kritis. Yogyakarta: Kreasi Wacana.

Butler, Yudith. 1990.

Gender Trouble: Feminism and the Subversion of Identity. New York \& London: Routledge.

Kimung, 2012.

Rebels, Panceg Dina Galur. Bandung.

Miharja, 2012.

Metodologi Penelitian Kualitatif.

Yogyakarta: Kepel.

Strinati, Dominic. 2004.

Populer Culture. Pengantar Menuju

Teori Budaya Populer. Yogyakarta: ArRuzz Media.

Nusyahidah, Sharifah, et all. 2016.

Punk, Penentangan dan Poliik

Transnasionalisme. Malaysia: SIRD.

Suwardi Hasan, Sandi. 2011.

Pengantar Cultural. Yogyakarta: ArRuzz Media. 